\title{
Unique COI haplotypes in Hediste diversicolor populations in lagoons adjoining the Ionian Sea
}

\author{
Katerina Vasileiadou ${ }^{1,2, *}$, Christina Pavloudii ${ }^{2,3}$, Elena Sarropoulou ${ }^{2}$, \\ Nina Fragopoulou ${ }^{1}$, Georgios Kotoulas ${ }^{2}$, Christos Arvanitidis ${ }^{2}$ \\ ${ }^{1}$ Department of Biology, University of Patras, 26500 Patras, Greece \\ ${ }^{2}$ Institute of Marine Biology, Biotechnology and Aquaculture, Hellenic Centre for Marine Research, 71003 Heraklion, Crete, \\ Greece \\ ${ }^{3}$ Department of Biology, University of Crete, Voutes University Campus, 70013 Heraklion, Crete, Greece
}

\begin{abstract}
The present study examines the genetic diversity (using cytochrome $c$ oxidase subunit I [COI] haplotypes) of polychaete Hediste diversicolor populations in the Amvrakikos Gulf (western Greece) in order to test Cognetti's hypothesis on the formation of distinct isolated populations of species living in stressed transitional water habitats. To this purpose, the intraspecific diversity of $H$. diversicolor and the similarities among its populations in the brackish water habitats of the Eastern Mediterranean were investigated. Samples were collected from the lagoonal complex of Amvrakikos Gulf in 2010 and 2011. Analysis showed that populations in the Amvrakikos Gulf share unique haplotypes which are distinct from the haplotypes hitherto reported, suggesting that these populations are highly isolated. This evidence partially supports Cognetti's hypothesis. The results indicate that the genetic differentiation in the studied populations was probably caused by the complete isolation of the gulf and periodic hypoxic conditions during its formation history. The occurrence of unique haplotypes in the gulf underlines the importance of considering genetic diversity in the design of long-term biodiversity management and conservation plans.
\end{abstract}

KEY WORDS: Lagoons - Amvrakikos Gulf - Hediste diversicolor - COI - Genetic diversity · Phylogenetic network

\section{INTRODUCTION}

Several authors have pointed out that species are able to adapt under stressful environmental conditions (e.g. Garrity 1984, Hermes-Lima \& ZentenoSavín 2002, Sanford \& Kelly 2011). In 1992, Cognetti stated that in the populations living in stressed water habitats, the genotypes allowing survival dominate over all others. These genotypes may create new populations with limited gene flow. These populations gradually become distinct, and in some cases they are driven to reproductive isolation, which may ultimately lead to speciation (Cognetti \& Maltagliati 2000, Schluter 2001). Reproductive isolation between populations can be favored by local adaptation of

${ }^{*}$ Corresponding author: kvasileiadou@hcmr.gr organisms to the environmental attributes of their habitat (Schluter 2001). The characteristics of the transitional water systems can have a severe effect on the isolation of populations (Kelly et al. 2006). The physicochemical profile of these systems can act as a barrier to gene flow and the dispersal of the individuals (Bilton et al. 2002, Marshall et al. 2010). However, isolation of populations by environment is not easy to determine (Sexton et al. 2014).

Lagoons are considered as highly dynamic ecosystems (Cañedo-Argüelles et al. 2012, Duck \& da Silva 2012, Pérez-Ruzafa \& Marcos 2012). They experience strong variance in their physicochemical variables (Arvanitidis et al. 2005, Duck \& da Silva 2012, PérezRuzafa \& Marcos 2012), hydrology and material in-

(C) The authors 2016. Open Access under Creative Commons by Attribution Licence. Use, distribution and reproduction are unrestricted. Authors and original publication must be credited. 
flows (Viaroli et al. 2007, Chapman 2012, Guilhaumon et al. 2012). Mediterranean lagoons often suffer from dystrophic crisis events (Guelorget \& Perthuisot 1992). The events are characterized by extremely high concentrations of organic matter, which in turn, increase microbial biomass. The excess rates of microbial respiration activity cause tremendously high oxygen consumption rates, leading to oxygen depletion and to mass mortality of the higher taxa populations (Vignes et al. 2009). Only a few species are able to tolerate these conditions (Cognetti \& Maltagliati 2000, Chapman 2012). Mediterranean lagoons are often subject to anthropogenic activities (Duck \& da Silva 2012), which, along with natural disturbance, may shape the environmental conditions of the ecosystems (Viaroli et al. 2007).

The lagoonal complex of Amvrakikos Gulf is one of the largest and most important Greek wetlands and is protected under the Ramsar convention. Dystrophic events have often been reported in the gulf (Kormas et al. 2001, Reizopoulou \& Nicolaidou 2007). Its formation history is similar to the formation of the Mediterranean and Black Seas in that there were periods of complete or partial (via narrow straits) isolation from the Ionian Sea (Avramidis et al. 2014). This eventful geological history of the Amvrakikos Gulf may have influenced the marine populations living there.

The nereidid polychaete Hediste diversicolor (O. F. Müller, 1776) is one of the dominant species found in the Amvrakikos lagoons (Reizopoulou \& Nicolaidou 2004). This species is a common inhabitant of lagoons and estuaries (Scaps 2002), appears to be the most euryhaline (Kristensen 1983) and tolerant to heavy metals (Hateley et al. 1992) compared to the other nereidid species and is considered to be very wellstudied in terms of both life-cycle and genetic diversity. Morphological and physiological differences across populations from different geographical ranges have been noted, as the populations in southern Europe appear to reach the reproductive stage earlier than the populations in northern Europe (Scaps 2002). The species shows limited dispersal ability due to larval incubation by the female and the lack of a pelagic phase (Scaps 2002, PolytraitsTeam 2013 (Faulwetter et al. 2014)).

$H$. diversicolor is considered to be cosmopolitan; however, high intraspecific diversity has been observed (Cossu et al. 2012). Audzijonyte et al. (2008) provided evidence for the existence of 2 cryptic species in the Baltic Sea, noted as Species A and Species B. Species A occurs mostly off the European Atlantic coast while for Species B, the authors suggested a recent introduction from the northwest Atlantic. However, Virgilio et al. (2009) found haplotypes of Species B in the Mediterranean, Black and Caspian Seas and argued for its introduction from these areas to the Baltic. Recently, unique haplotypes have been reported from the Gulf of Maine in North America (Einfeldt et al. 2014). These haplotypes are assumed to have been introduced into North American waters anthropologically from unknown populations off the European Atlantic coast and were characterized as being older than the ones identified by Audzijonyte et al. (2008).

The present study focuses on testing Cognetti's (1992) hypothesis that in transitional water ecosystems, isolated populations of species with limited dispersal potential may form distinct populations or even cryptic species (in extreme cases). In this study, the intraspecific diversity of $H$. diversicolor populations in eastern Mediterranean transitional ecosystems was examined, along with the extent of their isolation.

\section{MATERIALS AND METHODS}

The sampling area was located in Amvrakikos Gulf (western Greece) (Fig. 1). At the northern part of the Gulf, the Arachthos and Louros Rivers form a lagoonal complex. Hediste. diversicolor occurs in Rodia ( $\left.39^{\circ} 4^{\prime} \mathrm{N}, 20^{\circ} 48^{\prime} \mathrm{E}\right)$, Tsoukalio $\left(39^{\circ} 3^{\prime} \mathrm{N}, 20^{\circ} 48^{\prime} \mathrm{E}\right)$ and Tsopeli $\left(39^{\circ} 2^{\prime} \mathrm{N}, 20^{\circ} 46^{\prime} \mathrm{E}\right)$ Lagoons. Rodia is an internal lagoon, connected to Tsoukalio Lagoon through a narrow opening of $15 \mathrm{~m}$ width. Tsoukalio is separated from the sea by sand barriers with narrow openings allowing limited water exchange. Tsopeli is a small lagoon at the mouth of Louros River without any obvious source of pollution and less intensive anthropogenic activities as compared to the other lagoons. Samples were collected during 2010 and 2011.

Faunal samples were collected by a modified, manually operated, box-corer. Polychaetes were sorted in situ and all individuals were preserved in $95 \%$ ethanol. The taxonomic identification of $H$. diversicolor species was carried out by using the recent taxonomic key by Viéitez (2004). No size criterion was used for the $H$. diversicolor specimens. Morphometric data of the individuals were recorded during their taxonomic identification; however, they were not found to play an important role in the present analysis.

DNA from the polychaetes was isolated using a phenol/chloroform/isoamyl alcohol protocol. A fragment of cytochrome $c$ oxidase subunit I (COI) gene ( $304 \mathrm{bp})$ was amplified and sequenced using the 


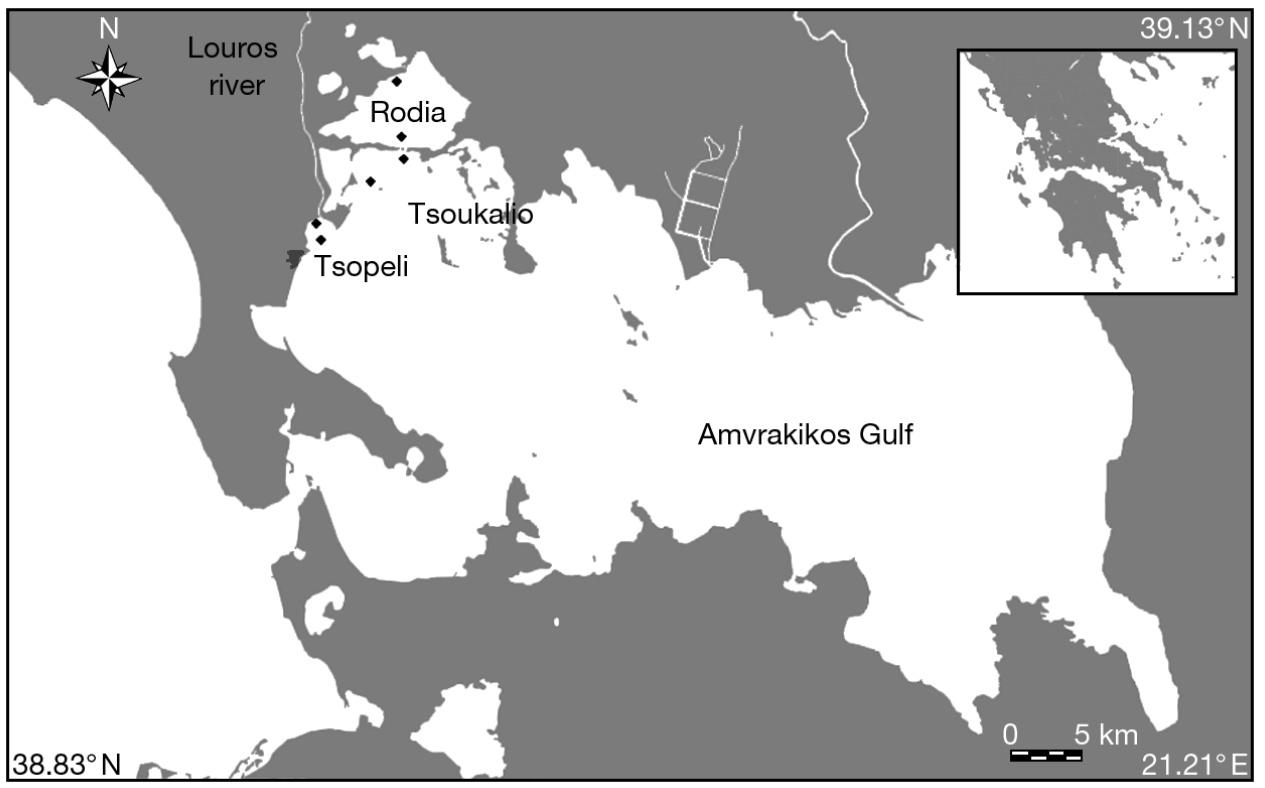

Fig. 1. Sampling locations in the lagoons in Amvrakikos Gulf, Greece

primers COIHedF (5'-ATG ATC AGG CCT TCT AGG-3') and COIHedR (5'-GGT GTT GGT AAA GGA TGG-3') designed for this study. Amplification reactions were of $30 \mu \mathrm{l}$ final volume and contained $3 \mu \mathrm{l}$ DNA template, $1 \mu \mathrm{l} 10 \times$ PCR buffer, $3.5 \mathrm{mM}$ $\mathrm{MgCl}_{2}, 0.6 \mu \mathrm{dNTPs}(100 \mathrm{mM}), 0.75 \mu \mathrm{l}$ of each primer $(10 \mathrm{mM}), 0.1 \mu \mathrm{l}$ KAPATaq DNA Polymerase (KAPA BIOSYSTEMS) and double-distilled water to the final volume. PCRs were carried out under the following thermal conditions: $94^{\circ} \mathrm{C}$ for $5 \mathrm{~min} ; 36$ cycles at $94^{\circ} \mathrm{C}$ for $1 \mathrm{~min}, 53^{\circ} \mathrm{C}$ for $2 \mathrm{~min}, 72^{\circ} \mathrm{C}$ for $1 \mathrm{~min} ; 72^{\circ} \mathrm{C}$ for $3 \mathrm{~min}$. Amplification products were sequenced in ABI3730 at the Genetics Lab of the Hellenic Centre for Marine Research. Sequences of different haplotypes acquired were submitted to GenBank (accession numbers are provided in Table $\mathrm{S} 1$ of the Supplement; at www.int-res.com/articles/suppl/b025 p007_supp.pdf). In total 87 individuals were sequenced.

The hitherto available sequences of COI gene from the European populations of $H$. diversicolor were downloaded from GenBank. Accession numbers of sequences used are shown in Table S1 in the Supplement. Sequences acquired from the database were all obtained from samples originating from polychaete samples of European transitional ecosystems. The sampling locations are distributed in the Baltic and North Seas, Atlantic Ocean, Mediterranean, Black and Caspian Seas. (Audzijonyte et al. 2008, Virgilio et al. 2009).

All sequences were aligned in MEGA v5 software with Clustal W algorithm (Tamura et al. 2011). Only the unique haplotypes (GenBank and Amvrakikos sequences; 121 sequences in total) were used for the Bayesian analysis. Bayesian analysis was carried out with MrBayes (Huelsenbeck \& Ronquist 2001), and the generalised time reversible (GTR) substitution model with gamma-distributed rate was chosen. Metropolis coupled Markov chain Monte Carlo (MCMCMC) was run for 10 million generations, trees were sampled every 1000 generations and 5000 trees were discarded. The sequences of $H$. atoka and $H$. japonica were used as an outgroup. The default values of MrBayes were chosen for all settings for MCMCMC analysis.

GenBank sequences originating from the Adriatic Sea (Lecce, Lamone, Pialassa, Croatia) were selected for the analysis in order to clarify the connectivity and phylogenetic distances of the Amvrakikos population to other populations of the eastern Mediterranean basin. Data from the Black Sea were also included due to the similarity in its formation history to the Amvrakikos Gulf. Median-joining phylogenetic networks were created with NETWORK 4.6.1.1 (Fluxus Technology). Haplotype $\left(H_{\mathrm{d}}\right)$ and nucleotide $(\pi)$ diversity indices were calculated and neutrality tests (Fu's F, Fu 1997 and Tajima's D, Tajima 1989) were applied in an attempt to assess whether the populations have experienced a recent expansion or have been subjected to a recent bottleneck or purifying selection (Lorenzo-Carballa et al. 2012). The significance of the values obtained was tested by random permutation using 1000 replicates. The ARLE- 
QUIN v.3.5 was used to apply the latter analyses (Excoffier \& Lischer 2010).

To estimate the isolation of populations, the pairwise fixation index $\left(F_{\mathrm{ST}}\right)$ was calculated. Analysis of molecular variance (AMOVA) was used to determine the variance between populations and within populations from the Amvrakikos Gulf, Adriatic and Black Seas. To test the significance in the intra- and interpopulation variance, 1023 permutations were used. The AMOVA analysis was performed using ARLEQUIN v.3.5 (Excoffier \& Lischer 2010).

Non-metric multidimensional scaling analysis (nMDS) was applied to give an estimation on the comparison between the populations based on haplotype frequencies from the Amvrakikos Gulf, Adriatic and Black Sea populations. The similarities were determined using the Bray-Curtis similarity index. PRIMER6 v.6.1.8 (Clarke \& Gorley 2006) was used (see Fig. S1 in the Supplement).

\section{RESULTS}

Bayesian analysis was applied to the aligned sequences of Hediste diversicolor (Fig. 2). The analysis shows that the haplotypes from the Amvrakikos lagoons have formed a distinct and strongly supported (posterior probability [PP] equal to $100 \%$ ) clade within the eastern Mediterranean clade (E Med clade). The E Med clade (PP = 99\%) also includes the sequences from the Adriatic Sea (Croatia, Lecce, Lamone and Pialassa), where the populations are found to share similar haplotypes. Moreover, the analysis shows most of the haplotypes from the Black Sea populations to be differentiated from those from the Mediterranean, the Atlantic, the North Sea and Kattegat, but some of them are grouped with populations from the Caspian and Baltic Seas.

A median-joining haplotype network was created based on the sequences included in the E Med clade of the tree created by the Bayesian analysis and the sequences from the Black Sea (Fig. 3). On the network, the haplotypes were clustered into 3 haplogroups: one including the haplotypes from the Adriatic Sea, a second one with the sequences from the Black Sea and a third one with the haplotypes from Amvrakikos Gulf. The group with the haplo- types from the Adriatic Sea included the populations from Lamone, Lecce and Croatia, which share the same haplotype. The same haplotype was also found in the Pialassa lagoon population. However, 2 more haplotypes were observed in the latter lagoon. The haplotypes from the Black Sea form a complex haplogroup consisting of 8 different haplotypes. The maximum distance among the Black Sea haplotypes was estimated to be 27 mutational steps, while the distance between the most frequent haplotypes of the Black and Adriatic Seas was calculated to be 31 mutational steps. The population from Greece showed clear separation from the rest. The distance between the most frequently occurring haplotypes in the Adriatic Sea and the Amvrakikos Gulf was found to be 12 mutational steps. The existence of 2 different haplotypes in the Greek lagoons in our study is evident, with one of them being dominant. These haplotypes are unique in that they have never been reported from any other place so far.

The haplotype and nucleotide diversity indices $\left(H_{\mathrm{d}}\right.$ and $\pi$ ) and neutrality tests (Tajima's $D$ and Fu's $F$ ) were calculated for the populations of Amvrakikos Gulf, Black and Adriatic Seas (Table 1). Both $H_{\mathrm{d}}$ and $\pi$ showed low scores for the samples from Amvrakikos Gulf (Table 1). For the Pialassa population the $H_{\mathrm{d}}$ was relatively high but $\pi$ was low (Table 1 ). Both indices were high for the Black Sea population (Table 1). Only the Tajima's $D$ value for the Amvrakikos population was found to be significant $(\mathrm{p}<$ 0.05 ). The negative $D$ value is indicative of a recovery from a bottleneck (or recent expansion or purifying selection) in the population. Both indices show negative values for the Amvrakikos population, whereas they show positive values for the Black and Adriatic Sea populations.

Pairwise $F_{\mathrm{ST}}$ values were estimated between the different populations (Table 2). It should be pointed out that the significant values were remarkably high $(>0.65)$ between Amvrakikos and all the other locations. The significant values between the Black Sea and the Adriatic locations (Pialassa, Lecce, Lamone and Croatia) were $>0.25$.

Results of the AMOVA analysis showed that ca. $61 \%$ of genetic polymorphism was due to differences between the groups (Table 3). $F_{\mathrm{ST}}(0.66)$ and $F_{\mathrm{CT}}$ (0.61) were found to be high $(>0.5)$.

Fig. 2. Bayesian analysis of COI haplotypes from the Amvrakikos Gulf and haplotypes identified by Audzijonyte et al. (2008) and Virgilio et al. (2009). Posterior probability (PP) values are shown on the tree branches. Group sp. A, B and AB refer to Species A, B and AB from the Baltic Sea, respectively 
Hediste atok

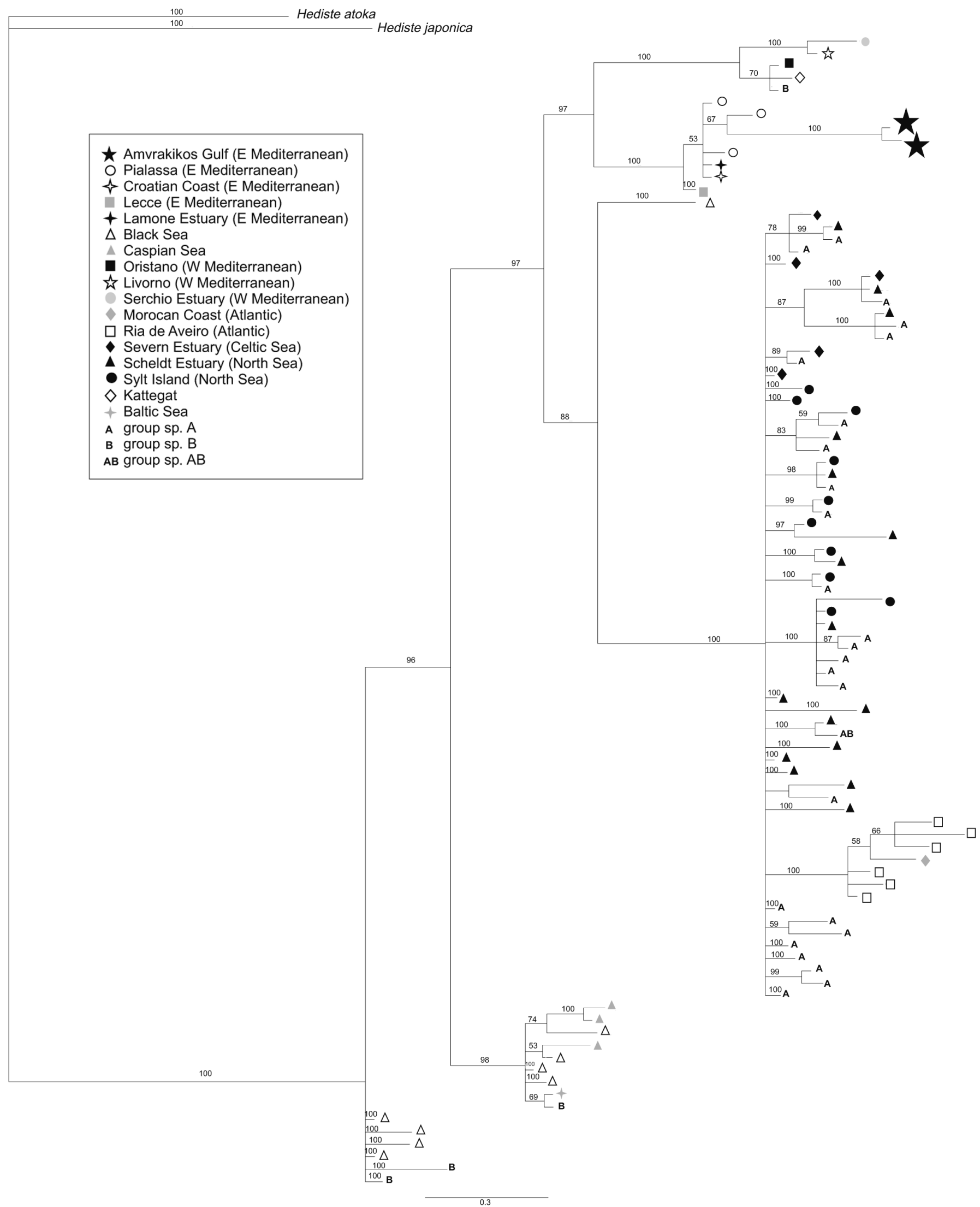




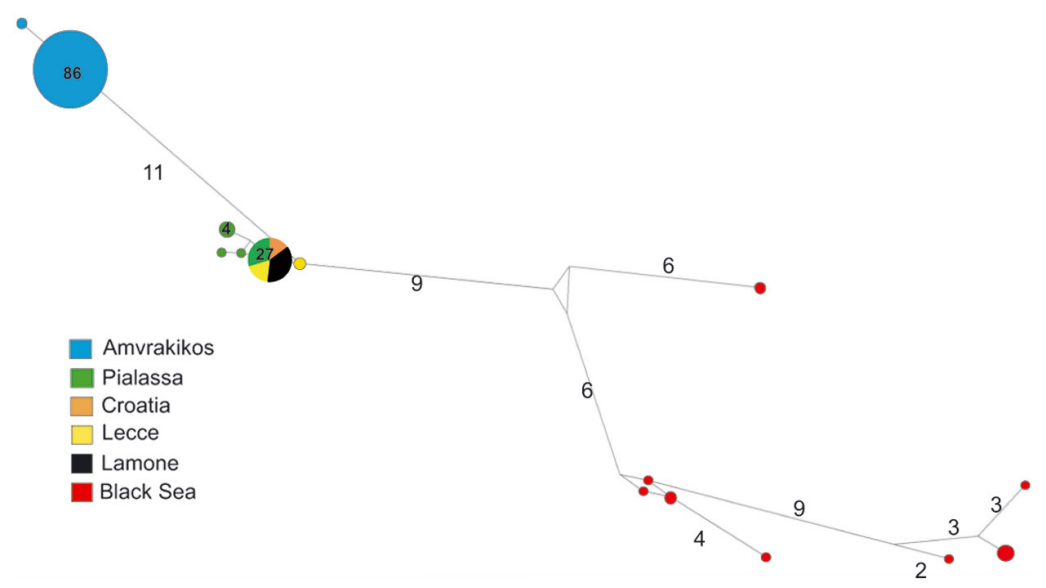

Fig. 3. Median-joining phylogenetic network of haplotypes sampled in the Amvrakikos Gulf and haplotpyes identified by Audzijonyte et al. (2008) and Virgilio et al. (2009). The size of the circles is proportional to the frequency of the haplotypes. Numbers on the branches represent the number of mutational steps. Numbers on the nodes represent the haplotypic frequencies (for frequencies $>2$ )

Table 1. Haplotype diversity index $\left(H_{\mathrm{d}}\right)$, nucleotide diversity index $(\pi)$ and neutrality tests (Tajima's $D$ and Fu's $F$ ) calculated by population in the Ionian (Amvrakikos Gulf), Adriatic (Pialassa, Lecce, Lamone, Croatia) and Black Seas. n: sample size. Significant values are shown in bold (Tajima's D: p $<0.05$; Fu's F: p < 0.02)

\begin{tabular}{|lccccc|}
\hline & $\mathrm{n}$ & \multirow{2}{*}{$H_{\mathrm{d}}$} & \multirow{2}{*}{$\pi$} & \multicolumn{2}{c|}{$\begin{array}{c}\text { Neutrality tests } \\
\text { Tajima's } D\end{array}$} \\
& & & & & Fu's $F$ \\
\hline Amvrakikos & 87 & 0.054 & 0.0004 & $\mathbf{- 1 . 4 9 3}$ & -0.586 \\
Black Sea & 13 & 0.897 & 0.038 & 1.237 & 1.583 \\
Pialassa & 14 & 0.626 & 0.0040 & 0.826 & -0.023 \\
Lecce & 7 & 0.476 & 0.0016 & 0.559 & 0.589 \\
Lamone & 10 & 0 & 0 & 0 & 0 \\
Croatia & 4 & 0 & 0 & 0 & 0 \\
\hline
\end{tabular}

Table 2. Population pairwise $F_{\mathrm{ST}}$ values comparing populations in the Ionian (Amvrakikos Gulf), Adriatic (Pialassa, Lecce, Lamone, Croatia) and Black Seas. Significant values are shown in bold $(\mathrm{p}<0.05)$

\begin{tabular}{|llllll|}
\hline \multicolumn{5}{|c|}{ Amvrakikos } & Black Sea \\
\hline Black Sea & $\mathbf{0 . 6 7 3}$ & & & & \\
Pialassa & $\mathbf{0 . 7 6 6}$ & $\mathbf{0 . 3 9 5}$ & & & \\
Lecce & $\mathbf{0 . 8 6 9}$ & $\mathbf{0 . 4 2 5}$ & 0.057 & & \\
Lamone & $\mathbf{0 . 9 1 3}$ & $\mathbf{0 . 2 8 3}$ & 0.128 & 0.076 & \\
Croatia & $\mathbf{0 . 9 5 1}$ & $\mathbf{0 . 3 9 5}$ & 0.099 & 0.057 & -0.121 \\
\hline
\end{tabular}

\section{DISCUSSION}

Based on our results, the intra-population diversity of Hediste diversicolor in the Greek lagoons is low. Both the low values of $H_{\mathrm{d}}$ and $\pi$ and the nonsignificant value of Fu's $F$ (Table 1) for the Am- vrakikos populations suggest either a recent bottleneck event, a founder effect or purifying selection (Lowe et al. 2004). However, the strong divergence of the haplotypes renders the founder event scenario less plausible. Moreover, regardless of the exceptions that have been reported in several animal groups, there are few possibilities of purifying selection to be detected on the mtDNA of invertebrates (Galtier et al. 2009), inferring that the recovery of the population from a bottleneck event is the most possible explanation. Such events have most probably occurred several times in the past in the studied area, as the lagoons are frequently subject to anoxic crises in the period ranging from the end of summer to the end of autumn, during which time a great number of individuals may well die. The phenomenon is not new in the area. Avramidis et al. (2014) pointed out hypoxic events during the Holocene, indicating that these bottleneck events may have been the result not only of anthropogenic activity but also of natural processes (disturbance). Low genetic diversity in the broader Amvrakikos Gulf area was also reported for the fish Aphanius fasciatus from restriction fragment length polymorphism (RFLP) data, a fact which was attributed to bottleneck processes or to the fluctuating conditions of the lagoonal habitat (Triantafyllidis et al. 2007). However, this did not seem to be the case for the crustacean Carcinus aestuarii (Ragionieri \& Schubart 2013). The abovementioned authors examined the diversity of the COI gene from the latter species and reported high haplotype diversity within the Amvrakikos populations, which seemed to be in expansion. Nevertheless, restricted gene flow, but not complete isolation, was observed between the population from Amvrakikos and the populations of the southern Ionian and Adriatic Seas (Ragionieri \& Schubart 2013). However, this crustacean species is characterized by a $6 \mathrm{wk}$ larval pelagic phase (Darling et al. 2008, Ragionieri \& Schubart 2013), as opposed to $H$. diversicolor, whose life history does not include such a phase (PolytraitsTeam 2013 (Faulwetter et al. 2014)).

The genetic polymorphism was found to be similarly low within the Pialassa population, comparable to that reported by Virgilio et al. (2003), who examined allozymic patterns from populations of $H$. diversicolor in the same lagoon. This phenomenon commonly occurs in species inhabiting lagoons where the stressful and fluctuating environmental conditions 
Table 3. Analysis of molecular variation (AMOVA) analysis showing the sum of squares (SS), variance components, percentage of variation and fixation indices. The regions Adriatic, Black Sea, Amvrakikos were defined as groups; Croatia, Lecce, Lamone and Pialassa were defined as populations within the group of Adriatic Sea

\begin{tabular}{|lccccc|}
\hline $\begin{array}{l}\text { Source of } \\
\text { variation }\end{array}$ & df & $\mathrm{SS}$ & $\begin{array}{c}\text { Variance } \\
\text { components }\end{array}$ & $\begin{array}{c}\text { \% of } \\
\text { variation }\end{array}$ & $\begin{array}{c}\text { Fixation } \\
\text { index }\end{array}$ \\
\hline Among groups & 2 & 9.914 & $0.294 \mathrm{Va}$ & 61.11 & $F_{\mathrm{CT}}: 0.611$ \\
$\begin{array}{l}\text { Among populations } \\
\text { within groups }\end{array}$ & 3 & 1.057 & $0.026 \mathrm{Vb}$ & 5.31 & $F_{\mathrm{SC}}: 0.136$ \\
$\begin{array}{l}\text { Within populations } \\
\text { Total }\end{array}$ & 129 & 12.142 & $0.161 \mathrm{VC}$ & 33.58 & $F_{\mathrm{ST}}: 0.664$ \\
& 134 & 30.59 & 0.481 & & \\
\hline
\end{tabular}

wise $F_{\text {ST }}$ calculations (Table 2). The population of the Amvrakikos Gulf lagoons appears to be completely isolated, as suggested by the remarkably high values resulting from the aforementioned analysis. The genetic homogeneity of the Adriatic populations was referenced from previous studies on allozyme markers (Virgilio et al. 2003, Virgilio \& Abbiati 2004). The gene flow between the Adriatic and Ionian Seas seems to be limited for several species, such as: Melicertus (Penaeus) kerathurus (Pellerito et al. 2009), Sepia officinalis (Pérez-Losada et

allow the establishment of a small number of tolerant individuals (Abbiati \& Maltagliati 1996). Nevertheless, $H$. diversicolor is considered to have lower genetic variability than other brackish water species, probably due to both transitional water constraints and the absence of a pelagic larval phase (Abbiati \& Maltagliati 1996, Röhner et al. 1997). Our analysis supports the probability of the population size reduction in the Italian lagoon. The results of this study are in accordance with those reported by Virgilio \& Abbiati (2004), who, nevertheless, did not report any bottleneck events for the Pialassa population of $H$. diversicolor.

The Bayesian analysis conducted by Virgilio et al. (2009) suggested the formation of 3 distinct clades: (a) the eastern Mediterranean, (b) the western Mediterranean and Kattegat and (c) the North Sea, Baltic and Atlantic Ocean. The population from Amvrakikos Gulf was ascribed to the Species B and is currently in the process of forming a separate distinct sub-clade within the eastern Mediterranean clade, indicating genetic distinction from the remaining populations of the Adriatic Sea, although they share a common ancestor. The distinction of the Greek haplotypes from those of the Adriatic and the Black Seas was also evident in the phylogenetic network and the AMOVA analysis (Fig. 3, Table 3). The population of $H$. diversicolor in the Amvrakikos Gulf is not the only case found to be genetically distant. Similar results have been reported from microsattelite and COI data of the crustacean Melicertus kerathurus (Pellerito et al. 2009, Arculeo et al. 2010). According to the authors, the COI haplotypes from Amvrakikos were not common with any other haplotype obtained during the analysis, suggesting that the population had been isolated for a long time (Pellerito et al. 2009).

The gene flow among the locations was demonstrated by the AMOVA analysis (Table 3) and pair- al. 2007), Carcinus aestuarii (Ragionieri \& Schubart 2013), and Aphanius fasciatus (Triantafyllidis et al. 2007). Isolation between the Ionian and Adriatic Seas has been ascribed to the current circulation in the area combined with differences in salinity, temperature and depth (Ragionieri \& Schubart 2013). Previous studies on $H$. diversicolor (Hateley et al. 1989, Abbiati \& Maltagliati 1996, Bilton et al. 2002), but also on other species such as $M$. kerathurus, A. fasciatus (Triantafyllidis et al. 2007, Pellerito et al. 2009), have attributed the genetic differentiation to both natural and anthropogenic environmental disturbance (i.e. heavy metals, salinity ranges).

The limited dispersal ability of $H$. diversicolor, combined with the natural and human disturbance in the lagoonal systems of Amvrakikos Gulf are probably responsible for the differentiation of the local population from the rest and for the potential recent bottleneck or founder event inferred by the results of our analyses. The formation history of the Amvrakikos Gulf, which occurred with limited or no connection at all to the Ionian Sea and with gradual flooding of the Gulf area with seawater, resembles, in this respect, the evolutionary history of the Black Sea (Avramidis et al. 2014). This event, along with dystrophic events, could account as the driving forces for the differentiation of the Amvrakikos haplotypes from the rest. The genetic differentiation of populations from different species inhabiting the Amvrakikos Gulf as reported from previous studies (e.g. Arculeo et al. 2010, Pellerito et al. 2009) support this scenario. The genetic isolation of the population, in combination with genetic drift, is responsible for the differentiation of the local population from the other populations used in the analysis. The low haplotypic diversity shows the strong effect of the environmental gradient on $H$. diversicolor populations in Amvrakikos Gulf, through natural selection. Additional investigation into the matter with the use of 
nuclear markers is essential in order to elucidate the contribution of these factors to the distinction of local communities.

The findings of the current study show that there is significant evidence to support in part the hypothesis formulated by Cognetti (1992): the genetic variability of the populations of $H$. diversicolor does not support the idea of sibling species but it does support the occurrence of populations in the lagoons of the Amvrakikos Gulf which are distinct from those in the eastern Mediterranean. In addition, the genetic differentiation of the species populations in the Amvrakikos Gulf was most probably caused by the complete isolation of the Gulf and periodic hypoxic conditions during its formation history, combined with the environmental state of the area. The populations in the Amvrakikos Gulf are genetically differentiated from the rest of the eastern Mediterranean region by showing unique haplotypes, thus providing the area with special features that should be seriously considered in the design of successful longterm management and conservation plans, as proposed by Cognetti \& Maltagliati (2004). However, the existing EU-relevant legislations (Water Framework Directive [WFD]; Marine Strategy Framework Directive [MSFD]) seem to ignore the occurrence of intraspecific genetic diversity and have not yet included a genetic approach in their current implementation phase. However, the first attempts to develop new indices of genetic diversity assessment (e.g. gAMBI, by Aylagas et al. 2014) for the implementation of the previously mentioned EU Directives have only just begun.

Acknowledgements. The authors acknowledge the Amvrakikos Management Body for information and assistance during samplings, as well as the collaborators of this study: Dr. Eugenia Apostolaki, Dr. Georgios Chatzigeorgiou, Dr. Eva Chatzinikolaou, Dr. Lucia Fanini, Dr. Evangelos Pafilis, Dr. Nafsika Papageorgiou, Federica Camisa and Irene Tsikopoulou, who we thank for their help and contributions. Many thanks to Dr. Didier Aurelle and Dr. Anne Chenuile for their suggestions and help during the genetic processing of the specimens. This study was supported by the EUBON project, funded by the European Union's Seventh Programme for research, technological development and demonstration under grant agreement No. 308454.

\section{LITERATURE CITED}

Abbiati M, Maltagliati F (1996) Allozyme evidence of genetic differentiation between populations of Hediste diversicolor (Polychaeta: Nereididae) from the western Mediterranean. J Mar Biol Assoc UK 76:637-647

Arculeo M, Pellerito R, Bonhomme F (2010) Isolation and use of microsatellite loci in Melicertus kerathurus (Crus- tacea, Penaeidae). Aquat Living Resour 23:103-107

Arvanitidis C, Chatzigeorgiou G, Koutsoubas D, Kevrekidis $\mathrm{T}$ and others (2005) Estimating lagoonal biodiversity in Greece: comparison of rapid assessment techniques. Helgol Mar Res 59:177-186

Audzijonyte A, Ovcarenko I, Bastrop R, Väinölä R (2008) Two cryptic species of the Hediste diversicolor group (Polychaeta, Nereididae) in the Baltic Sea, with mitochondrial signatures of different population histories. Mar Biol 155:599-612

Avramidis P, Iliopoulos G, Panagiotaras D, Papoulis D and others (2014) Tracking Mid- to Late Holocene depositional environments by applying sedimentological, palaeontological and geochemical proxies, Amvrakikos coastal lagoon sediments, western Greece, Mediterranean Sea. Quat Int 332:19-36

Aylagas E, Borja A, Rodríguez-Ezpeleta N (2014) Environmental status assessment using DNA metabarcoding: towards a genetics based marine biotic index (gAMBI). PloS one 9:e90529

Bilton DT, Paula J, Bishop JDD (2002) Dispersal, genetic differentiation and speciation in estuarine organisms. Estuar Coast Shelf Sci 55:937-952

Cañedo-Argüelles M, Rieradevall M, Farrés-Corell R, Newton A (2012) Annual characterisation of four Mediterranean coastal lagoons subjected to intense human activity. Estuar. Coast Shelf Sci 114:59-69

> Chapman PM (2012) Management of coastal lagoons under climate change. Estuar Coast Shelf Sci 110:32-35

Clarke K, Gorley R (2006) PRIMER v6: User manual/tutorial. PRIMER-E, Plymouth

> Cognetti G (1992) Colonization of stressed coastal environments. Mar Pollut Bull 24:12-14

Cognetti G, Maltagliati F (2000) Biodiversity and adaptive mechanisms in brackish water fauna. Mar Pollut Bull 40: $7-14$

Cognetti G, Maltagliati F (2004) Strategies of genetic biodiversity conservation in the marine environment. Mar Pollut Bull 48:811-812

> Cossu P, Maltagliati F, Lai T, Casu M, Curini-Galletti M, Castelli A (2012) Genetic structure of Hediste diversicolor (Polychaeta, Nereididae) from the northwestern Mediterranean as revealed by DNA inter-simple sequence repeat (ISSR) markers. Mar Ecol Prog Ser 452: 171-178

> Darling JA, Bagley MJ, Roman J, Tepolt CK, Geller JB (2008) Genetic patterns across multiple introductions of the globally invasive crab genus Carcinus. Mol Ecol 17: 4992-5007

> Duck RW, da Silva JF (2012) Coastal lagoons and their evolution: a hydromorphological perspective. Estuar Coast Shelf Sci 110:2-14

> Einfeldt AL, Doucet JR, Addison JA (2014) Phylogeography and cryptic introduction of the ragworm Hediste diversicolor (Annelida, Nereididae) in the northwest Atlantic. Invertebr Biol 133:232-241

> Excoffier L, Lischer HEL (2010) Arlequin suite ver 3.5: a new series of programs to perform population genetics analyses under Linux and Windows. Mol Ecol Resour 10: 564-567

> Faulwetter S, Markantonatou V, Pavloudi C, Papageorgiou $\mathrm{N}$ and others (2014) Polytraits: a database on biological traits of marine polychaetes. Biodivers Data J 2:e1024

Fu YX (1997) Statistical tests of neutrality of mutations against population growth, hitchhiking and background 
selection. Genetics 147:915-925

Galtier N, Nabholz B, Glémin S, Hurst GDD (2009) Mitochondrial DNA as a marker of molecular diversity: a reappraisal. Mol Ecol 18:4541-4550

Garrity SD (1984) Some adaptations of gastropods to physical stress on a tropical rocky shore. Ecology 65:559-574

Guelorget O, Perthuisot JP (1992) Paralic ecosystems: biological organization and functioning. Vie Milieu 42: 215-251

> Guilhaumon F, Basset A, Barbone E, Mouillot D (2012) Species-area relationships as a tool for the conservation of benthic invertebrates in Italian coastal lagoons. Estuar Coast Shelf Sci 114:50-58

Hateley JG, Grant A, Jones NV (1989) Heavy metal tolerance in estuarine populations of Nereis diversicolor. In: Ryland JS, Tyler AP (eds) Reproduction, genetics and distribution of marine organisms. Olsen \& Olsen, Fredensborg, p 379-385

Hateley JG, Grant A, Taylor SM, Jones NV (1992) Morphological and other evidence on the degree of genetic differentiation between populations of Nereis diversicolor. J Mar Biol Assoc UK 72:365-381

> Hermes-Lima M, Zenteno-Savín T (2002) Animal response to drastic changes in oxygen availability and physiological oxidative stress. Comp Biochem Physiol C Toxicol Pharmacol 133:537-556

> Huelsenbeck JP, Ronquist F (2001) MRBAYES: Bayesian inference of phylogenetic trees. Bioinformatics 17:754-755

Kelly DW, MacIsaac HJ, Heath DD (2006) Vicariance and dispersal effects on phylogeographic structure and speciation in a widespread estuarine invertebrate. Evolution 60:257-267

> Kormas KA, Nicolaidou A, Reizopoulou S (2001) Temporal variations of nutrients, chlorophyll $a$ and particulate matter in three coastal lagoons of Amvrakikos Gulf (Ionian Sea, Greece). Mar Ecol 22:201-213

Kristensen E (1983) Ventilation and oxygen uptake by three species of Nereis (Annelida: Polychaeta). I. Effects of hypoxia. Mar Ecol Prog Ser 12:289-297

Lorenzo-Carballa MO, Hadrys H, Cordero-Rivera A, Andrés JA (2012) Population genetic structure of sexual and parthenogenetic damselflies inferred from mitochondrial and nuclear markers. Heredity 108:386-395

Lowe A, Harris S, Ashton P (2004) Ecological genetics: design, analysis and application. Blackwell Publishing, Singapore

Marshall DJ, Monro K, Bode M, Keough MJ, Swearer S (2010) Phenotype-environment mismatches reduce connectivity in the sea. Ecol Lett 13:128-140

Pellerito R, Arculeo M, Bonhomme F (2009) Recent expansion of northeast Atlantic and Mediterranean populations of Melicertus (Penaeus) kerathurus (Crustacea: Decapoda). Fish Sci 75:1089-1095

Pérez-Losada M, Nolte MJ, Crandall KA, Shaw PW (2007) Testing hypotheses of population structuring in the northeast Atlantic Ocean and Mediterranean Sea using the common cuttlefish Sepia officinalis. Mol Ecol 16:2667-2679

Pérez-Ruzafa A, Marcos C (2012) Fisheries in coastal lagoons: an assumed but poorly researched aspect of the ecology and functioning of coastal lagoons. Estuar Coast

Editorial responsibility: Judith Grassle,

New Brunswick, New Jersey, USA
Shelf Sci 110:15-31

PolytraitsTeam (2013) A database on biological traits of polychaetes. LifewatchGreece, Hell Cent Mar Res

> Ragionieri L, Schubart CD (2013) Population genetics, gene flow, and biogeographical boundaries of Carcinus aestuarii (Crustacea: Brachyura: Carcinidae) along the European Mediterranean coast. Biol J Linn Soc 109:771-790

Reizopoulou S, Nicolaidou A (2004) Benthic diversity of coastal brackish-water lagoons in western Greece. Aquat Conserv 14:S93-S102

Reizopoulou S, Nicolaidou A (2007) Index of size distribution (ISD): a method of quality assessment for coastal lagoons. Hydrobiologia 577:141-149

Röhner M, Bastrop R, Jürss K (1997) Genetic differentiation in Hediste diversicolor (Polychaeta: Nereididae) for the North Sea and the Baltic Sea. Mar Biol 130:171-180

> Sanford E, Kelly MW (2011) Local adaptation in marine invertebrates. Annu Rev Mar Sci 3:509-535

Scaps P (2002) A review of the biology, ecology and potential use of the common ragworm Hediste diversicolor (O. F. Müller) (Annelida: Polychaeta). Hydrobiologia 470: 203-218

Schluter D (2001) Ecology and the origin of species. Trends Ecol Evol 16:372-380

Sexton JP, Hangartner SB, Hoffmann AA (2014) Genetic isolation by environment or distance: Which pattern of gene flow is most common? Evolution 68:1-15

Tajima F (1989) Statistical method for testing the neutral mutation hypothesis by DNA polymorphism. Genetics 123:585-595

Tamura K, Peterson D, Peterson N (2011) MEGA5: molecular evolutionary genetics analysis using maximum likelihood, evolutionary distance, and maximum parsimony methods. Mol Biol Evol 28:2731-2739

> Triantafyllidis A, Leonardos I, Bista I, Kyriazis ID and others (2007) Phylogeography and genetic structure of the Mediterranean killifish Aphanius fasciatus (Cyprinodontidae). Mar Biol 152:1159-1167

Viaroli P, Lasserre P, Campostrini P (2007) Preface. Hydrobiologia 577:1-3

Viéitez JM (2004) Fauna Ibérica, Vol 25: Annelida: Polychaeta I. Museo Nacional de Ciencias Naturales, Madrid

> Vignes F, Barbone E, Breber P, Adamo RD and others (2009) Spatial and temporal description of the dystrophic crisis in Lesina lagoon during summer 2008. Transitional Waters Bull 3:47-62

Virgilio M, Abbiati M (2004) Habitat discontinuity and genetic structure in populations of the estuarine species (Polychaeta: Nereididae). Estuar Coast Shelf Sci 61: 361-367

> Virgilio M, Baroncini N, Trombini C, Abbiati M (2003) Relationships between sediments and tissue contamination and allozymic patterns in Hediste diversicolor (Polychaeta Nereididae) in the Pialassa lagoons (north Adriatic Sea). Oceanol Acta 26:85-92

> Virgilio M, Fauvelot C, Costantini F, Abbiati M, Backeljau T (2009) Phylogeography of the common ragworm Hediste diversicolor (Polychaeta: Nereididae) reveals cryptic diversity and multiple colonization events across its distribution. Mol Ecol 18:1980-1994

Submitted: January 27, 2016; Accepted: April 4, 2016 Proofs received from author(s): May 16, 2016 